\title{
The Role of Efferocytosis in Autoimmune Diseases
}

\begin{abstract}
Fereshte Abdolmaleki', Najmeh Farahani ${ }^{2}$, Seyed Mohammad Gheibi Hayat ${ }^{3}$, Matteo Pirro ${ }^{4}$, Vanessa Bianconi ${ }^{4}$, George E. Barreto ${ }^{5,6}$ and Amirhossein Sahebkar ${ }^{7,8,9 *}$

${ }^{1}$ Cellular and Molecular Research Center, School of Paramedical Sciences, Qazvin University of Medical Sciences, Qazvin, Iran, ${ }^{2}$ Department of Genetics and Molecular Biology, Isfahan University of Medical Sciences, Isfahan, Iran, ${ }^{3}$ Department of Genetics, School of Medicine, Shahid Sadoughi University of Medical Sciences, Yazd, Iran, ${ }^{4}$ Unit of Internal Medicine, Angiology and Arteriosclerosis Diseases, Department of Medicine, University of Perugia, Perugia, Italy, ${ }^{5}$ Departamento de Nutrición y Bioquímica, Facultad de Ciencias, Pontificia Universidad Javeriana, Bogotá, Colombia, ${ }^{6}$ Instituto de Ciencias Biomédicas,

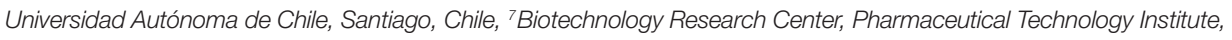
Mashhad University of Medical Sciences, Mashhad, Iran, ${ }^{8}$ Neurogenic Inflammation Research Center, Mashhad University of Medical Sciences, Mashhad, Iran, ${ }^{9}$ School of Pharmacy, Mashhad University of Medical Sciences, Mashhad, Iran
\end{abstract}

Apoptosis happens continuously for millions of cells along with the active removal of apoptotic debris in order to maintain tissue homeostasis. In this respect, efferocytosis,

OPEN ACCESS

Edited by:

Laurence Morel,

University of Florida,

United States

Reviewed by:

Sun Jung Kim,

Northwell Health,

United States

Kerstin Nundel,

University of Massachusetts Medical School, United States

*Correspondence: Amirhossein Sahebkar sahebkara@mums.ac.ir, amir_saheb2000@yahoo.com

Specialty section:

This article was submitted

to Autoimmune and

Autoinflammatory Disorders,

a section of the journal

Frontiers in Immunology

Received: 02 April 2018

Accepted: 04 July 2018

Published: 20 July 2018

Citation:

Abdolmaleki F, Farahani $N$,

Gheibi Hayat SM, Pirro M, Bianconi V,

Barreto GE and Sahebkar A (2018)

The Role of Efferocytosis in

Autoimmune Diseases.

Front. Immunol. 9:1645.

doi: 10.3389/fimmu.2018.01645 i.e., the process of dead cell clearance, is orchestrated through cell exposure of a set of "find me," "eat me," and "tolerate me" signals facilitating the engulfment of dying cells through phagocytosis by macrophages and dendritic cells. The clearance of dead cells via phagocytes is of utmost importance to maintain the immune system tolerance to self-antigens. Accordingly, this biological activity prevents the release of autoantigens by dead cells, thus potentially suppressing the undesirable autoreactivity of immune cells and the appearance of inflammatory autoimmune disorders as systemic lupus erythematous and rheumatoid arthritis. In the present study, the apoptosis pathways and their immune regulation were reviewed. Moreover, efferocytosis process and its impairment in association with some autoimmune diseases were discussed.

Keywords: apoptosis, efferocytosis, autoimmune disease, phagocytosis, systemic lupus erythematous

\section{INTRODUCTION}

During the lifespan of the human body, a huge number of cells die after fulfilling their functions in each tissue (1). In this regard, apoptosis is a highly organized process of cellular suicide and programmed cell death, which is critical to control body homeostasis and to regulate tissue development (2). The removal of cell corpses through different signaling is performed by phagocytic and dendritic cells of the innate system in physiological conditions. Immediately after apoptosis, phagocytes are recruited by appropriate "find me" signals and, after "eat me" signals are released, they may finally engulf the apoptotic cells (3). The appropriate operation of cell corpse clearance, termed as efferocytosis, is imperative for organ development, tissue adjustment, and accomplishment of a proper immune response (4). Failure in the process of dead cell clearance may lead to various disorders, including autoimmune diseases such as systemic lupus erythematous

\footnotetext{
Abbreviations: BA1, brain-specific angiogenesis inhibitor 1; C1q, complement 1q; CRT, calreticulin; LPC, lysophosphatidylcholine; LXR, liver X receptor; MFG-E8, milk fat globule-EGF factor 8; PPAR $\delta / \gamma$, peroxisome proliferator-activated receptor $\gamma / \delta$; RA, rheumatoid arthritis; SLE, systemic lupus erythematous; S1P, sphingosine-1-phosphate; ATG, autophagy-related gene; LAP, LC3-associated phagocytosis; TLR1/2, toll-like receptor 1/2; TIM, T cell immunoglobulin mucin receptor; DAMP, danger-associated molecular pattern.
} 
(SLE), rheumatoid arthritis (RA), and type 1 diabetes (T1D) $(5,6)$. Thus, a growing interest has mounted in recent years on the mechanisms, modulation, and correlation of dead cell clearance in specific illnesses (4). In this review, the molecular pathways occurring during apoptosis, the role of efferocytosis as a modulator of immune response and the mechanisms leading to the omission of cell corpse removal by professional and nonprofessional phagocytic cells are outlined.

\section{APOPTOSIS MECHANISM}

Apoptosis, as a homeostatic process, happens during development and aging in order to promote embryogenesis and maintain cell population in organs and tissues (7). Numerous studies employing different techniques such as the terminal deoxynucleotidyl transferase (TdT) dUTP Nick-End Labeling (TUNEL) assay and real-time qPCR have revealed that such a natural mechanism is characterized by the activation of different pathways (e.g., caspases pathway) and several morphological changes including cell shrinkage, blebbing, chromatin condensation, and DNA fragmentation $(8,9)$. Finally, the apoptotic process should be terminated by the phagocytosis of the apoptotic corpses, which are enveloped with their entire plasma membrane. Immediate phagocytosis of these apoptotic cells by macrophages prevents cell secondary necrosis and the release of cellular debris, thus avoiding inflammatory reactions, as well as anti-inflammatory cytokines production (10).

As anticipated, one of the most important feature of apoptotic pathways is the presence and activation of caspase proteins. Such proteins are expressed in the form of an inactive proenzyme in most cells, but their activation induces the initiation of a protease cascade leading to apoptotic signaling pathway as well as rapid cell death (7). There are different kinds of caspases endowed with various potentials including initiator caspases $(2,8,9$, and 10 caspases), effector or executioner caspases ( 3,6 , and 7 caspases), as well as inflammatory ones (1, 4, and 5 caspases). Besides, all of them have a common feature, that is, a proteolytic activity to separate proteins at aspartic acid residues (11). Apoptotic cells have also some biochemical characteristics to be recognized by phagocytes in order to have minimum engagement with their surrounding tissues. These features include: (1) the translocation of phosphatidylserinee (PS) to the external layer of the plasma membrane, (2) and the expression of calreticulin (CRT) and annexin 1 proteins on the surface of apoptotic cells (12). CRT, as a second general recognition ligand, can be recognized by an LDL receptor-related protein on the engulfing cells, together with the interaction between the apoptotic and engulfing cells mediated by the general recognition ligand PS, which colocalizes with CRT on the surface of apoptotic cell and acts as a detection signal for phagocytes. Hence, the interaction of annexin $\mathrm{V}$ as a recombinant PS-binding protein with PS residues is able to facilitate the recognition of apoptosis and the combined action of PS and CRT is important for optimal apoptotic-cell recognition and uptake of apoptotic cells (13).

Two main pathways of apoptosis include extrinsic or death receptor pathway and intrinsic or mitochondrial pathway, which are induced via extracellular signaling and mitochondrial proteins, respectively (14). To initiate the apoptosis process via an extrinsic pathway, two central receptor-mediated interactions are involved: fatty acid synthase ligand and receptor (FasL/Fas R) and tumor necrosis factor-alpha and receptor (TNF- $\alpha /$ TNF R) (15). Binding of FasL to Fas R can lead to the constitution of the death-inducing signaling complex containing Fas-associated death domain protein (FADD), caspase 8, and caspase 10. This process is followed by the activation of executioner caspases 3,6, and 7, as well as the induction of cell death (16). In addition, signaling through TNF ligand to TNF R can result in the binding of the adaptor protein TNF receptor-associated death domain (TRADD) utilizing FADD and receptor-interacting protein and inducing apoptosis in a caspase-independent manner $(16,17)$.

The main function of the intrinsic apoptosis pathway is related to mitochondria. Various factors including DNA damage, hypoxia, radiations, heat, and viral infections may cause mitochondrial swelling and membrane permeabilization, followed by leaking out of apoptotic effectors $(18,19)$. Such a mechanism starts via releasing the second mitochondria-derived activator of caspases (SMAC) into the cytosol and enhancing the permeability of the mitochondria membranes. Moreover, SMAC is able to deactivate the proteins hindering apoptosis (IAPs), thus allowing apoptosis to continue (20). In another way, due to the formation of a channel in the outer membrane of mitochondria, that is the mitochondrial apoptosis-induced channel (21), cytochrome $\mathrm{C}$ is extracted, thus promoting caspase 9 activation and related morphological changes in association with apoptosis (e.g., changes in the nucleus, DNA fragmentation, PS appearance on the cell surface). Accordingly, binding of cytochrome $\mathrm{C}$ to apoptotic protease activating factor-1 (Apaf-1) and ATP can lead to its connection to pro-caspase9 in order to produce a set of proteins known as apoptosomes. The activity of apoptosome can also change the procaspase to its active form (caspase9) followed by the activation of effector caspase-3 (18). Mitochondrial functions during apoptosis can be also controlled and regulated via members of B-cell lymphoma protein 2 (BCL2 ) protein family (22). The BCL-2 family members include both proapoptotic proteins [e.g., BCL2-associated X protein (Bax), BCL2 antagonist killer 1 (Bak), BH3-interacting domain death agonist (Bid), BCL2 antagonist of cell death (Bad), and BCL2interacting protein BIM (Bim)] and antiapoptotic proteins [BCL-2, BCL2 related protein, long isoform (BCL-xl), BCL2 related protein, short isoform (BCL-xs), and BCL2 associated athanogene (BAG)]. These proteins are of particular importance in order to determine cell fate, i.e., apoptosis or prevention of the mechanism. In this sense, the release of cytochrome $\mathrm{C}$ from the mitochondria to the cytosol can be regulated by changing the mitochondrial membrane permeability via BCL2- family proteins (7).

There is a connection between the extrinsic and intrinsic apoptosis pathways. First, the activation of the extrinsic pathway by Fas domain leads to the activation of Bid to Truncated Bid (tBid) via caspase 8-mediated cleavage. Then, tBid binds and inhibits Bcl-2 and also stimulates oligomerization of Bax or Bak, leading to the release of cytochrome $\mathrm{C}$ and the activation of the internal pathway $(23,24)$. 


\section{Apoptotic Versus Non-Apoptotic Cell Death}

In addition to programmed cell death (i.e., apoptosis), accumulating evidence has led to a better comprehension of additional types of cell death, including necrosis, necroptosis, pyroptosis, and ferroptosis. Different stimuli including ischemia, pathogens, irradiation, heat, or cytokines may promote necrosis. Since necrosis is a passive mode of cell death, it has been suggested initially that there was no specific mechanism in association with necrotic cell death; however, it is now clear that necrotic cell death has multiple subtypes, greatly organized by particular molecules. For instance, mixed lineage kinase domain-like, receptor interacting serine/threonine kinase 1, receptor interacting serine/ threonine kinase 3 (RIPK3) have been established to contribute to a subtype of necrosis termed necroptosis (25), whereas another subtype of necrotic cell death, i.e., pyroptosis, is in association with caspase-1-mediated cell death (26). An additional subtype of non-apoptotic cell death requiring iron ions is named ferroptosis (27). It was revealed that these new subtypes of cell death, albeit sharing some common mechanisms, may be differently regulated. However, there is not enough evidence on the physiological activity of these new subtypes of cell death and on the differential response of macrophages and dendritic cells to these types of cell death. In addition, it is still unclear whether the specific form of cell death can determine the procedure of dead cell clearance.

\section{MECHANISM OF EFFEROCYTOSIS}

Several billion cells are dying in the human body to ensure cellular homeostasis, wound healing, and immune responses. In order to allow all these processes, the dying cells should be efficiently removed (28). The process of dead cell clearance, termed as efferocytosis, is normally done in an orchestrated mechanism in the human body through lifespan (29). Due to the released signals from dead cells and phagocytes, both professional (i.e., macrophages and dendritic cells) and non-professional cells (i.e., epithelial cells and fibroblasts) participate actively to apoptotic corpses identification and engulfment in order to degrade them $(30,31)$. The engulfment process of apoptotic cells by phagocytes, before apoptotic cells release their immunogenic intra-cellular contents, is considered as an immunological event. Accordingly, impairment of this process can lead to numerous autoimmune disorders such as SLE, RA, and other diseases (32). Altogether, the efferocytosis process can be classified into four steps: (1) the leaking of the "find me" signal by dead cells to recruit phagocytes, (2) phagocyte identification and its contribution to the "eat me" signals on the cellular corpse, (3) the engulfment of dead cells, and (4) the degradation of the engulfed cells (3).

\section{"Find-Me" Signals}

Accumulating evidence demonstrated that the dying cells are able to reveal their presence to phagocytes (33). Specifically, based on the acquired data from Caenorhabditis elegans, it was realized that recruitment of phagocytes to the area of cell death can happen before cell apoptosis is completed $(34,35)$. Expression of various "find me" signals by apoptotic cells can attract phagocytic cells through a chemotactic gradient (36). Four main "find me" signals have been described, including nucleotides, CX3CL1, lysophosphatidylcholine (LPC), and sphingosine-1-phosphate (S1P).

The caspase-dependent release of nucleotides as ATP and UTP through pannexin-1 (panx1) channels is believed as a crucial "find me" signal (37), which can result in warning phagocytes to cooperate with purinergic receptors (e.g., P2Y2) and removal of dead cells (33).

During maturation of B cells, lots of them will be apoptosed and release the membrane-associated molecule CX3CL1 (fractalkine), whose recognition by CX3CR1 can modulate the migration of macrophages toward the dying B cells. Although experiments conducted on mice with CX3CR1 deficiency shed light on the migration of macrophages toward apoptotic B cells, the mechanisms of apoptotic B cell clearance by phagocytic cells needs to be clarified (38).

Lysophosphatidylcholine, which is another "find me" signal, is produced and released through caspase-3-dependent activation of phospholipase A2. There is evidence that ATP-binding cassette transporter A1 may be necessary for LPC release by apoptotic cells (39). This lipid signal is mediated by the G-protein-coupled receptor G2A on macrophages (40). The other lipid "find me" signal, released by dead cells, is $\mathrm{S}_{1} \mathrm{P}$, which is generated from sphingosine by sphingosine kinase and sensed via multiple G-protein-coupled receptors (i.e., $\left.\mathrm{S}_{1} \mathrm{P}-\mathrm{R} 1-5\right)$ to regulate phagocyte chemotaxis (41).

In comparison with necrosis or necroptosis, the discharge of nucleotides from apoptotic cells is small and the released nucleotides can be easily degraded by extracellular nucleotidases (36). In addition to the release of a low amount of extracted nucleotides $(<2 \%$ of intra-cellular ATP) (33), the "find me" signals of lipid origin during apoptosis all act in a short-range to engage phagocytes (32).

There are additional issues that make the efferocytosis process even more intricate. For instance, apoptotic cells may release also lactoferrin glycoprotein that acts as a "keep me" signal and refuses neutrophils and eosinophils from the area of cell death $(42,43)$. Thus, the balance between "find me" and "keep me" signals might be crucial for the final destination of the apoptotic debris. Another finding in this domain is the double role of the "find me" signal as danger-associated molecular pattern to activate innate immune system (44) or stimulating factors to prime phagocytes (45).

In conclusion, since dying/dead cells together with healthy cells and immune cells coexist in the body, the phagocytes should be able to distinguish dying/dead cells from living ones, while dying/dead cells should display specific signals in order to be differentiated from living cells and to be engulfed by phagocytes $(46,47)$, thus preventing undesirable inflammation and ensuring tissue homeostasis (Figure 1A). Although some functions of the reported "find me" signals have been clearly described (e.g., producing cells, releasing pathways, target cells), there are still several open questions regarding the possible interaction (either positive or negative) between both "find me" and "keep me" signals and target cells. First, it is unclear whether "find me" and "keep me" signals may be cell-specific, so that different dying cells may preferentially recruit different phagocytes. Second, it is not established as to whether different "find me" and "keep me" signals at various concentrations and distances from phagocytes 


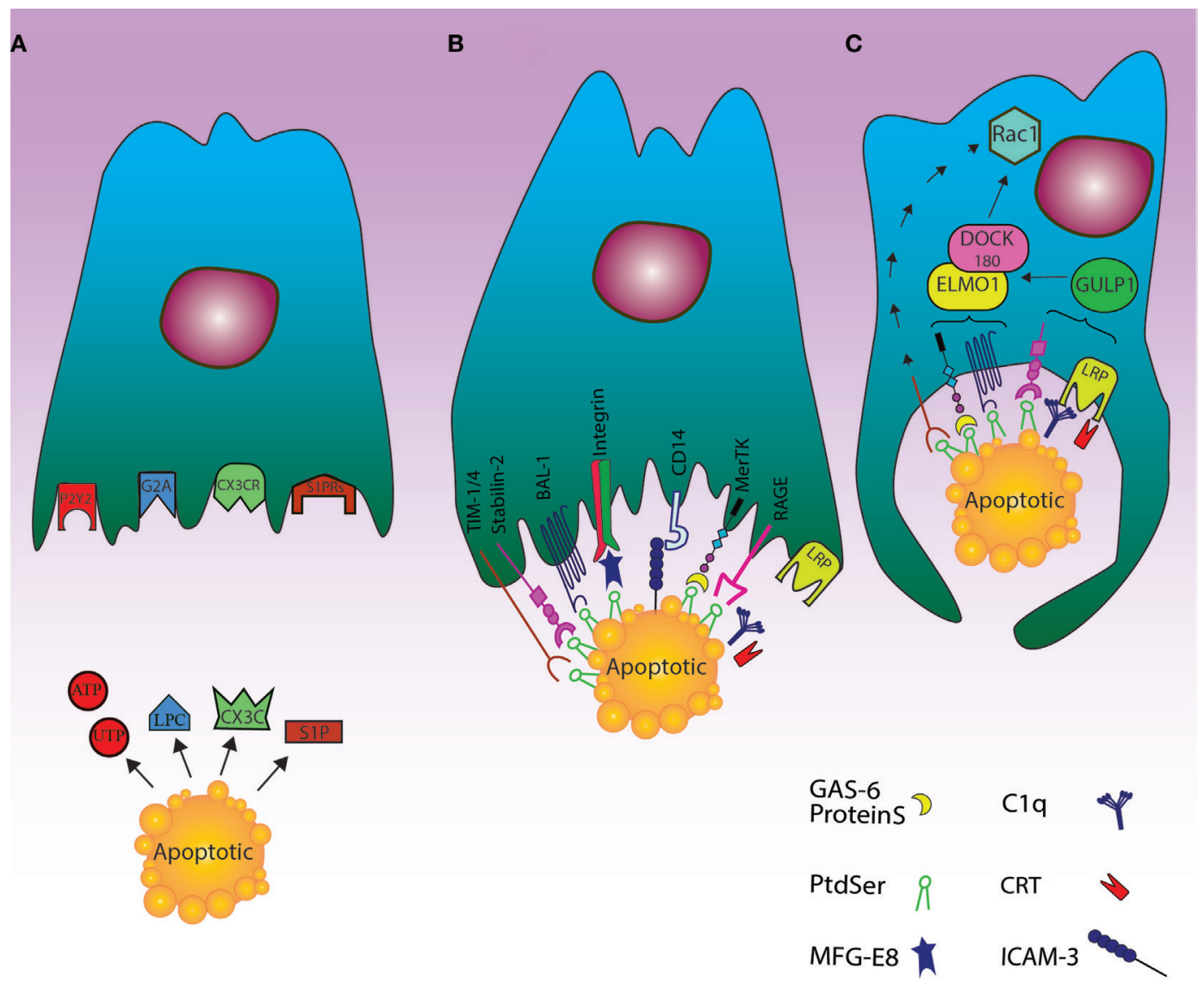

FIGURE 1 | Cell death clearance processing by phagocytes through finding apoptotic cells, recognition their signals and engulfment of the cell corpses. (A) The "find me" signal: the dying cells release signals such as UTP, ATP, sphingosine-1-phosphate (S1P), and lysophosphatidylcholine or fractalkine through apoptosis. These "find me" signals can also conduct phagocytes to the location of cell death. Phagocytes can thus sense the "find me" signal to detect apoptotic cells using cognate receptors including sphingosine-1-phosphate receptor (S1PRs), purinergic receptors (P2Y2), G-protein-coupled receptor (G2A), and CXCR3. (B) The "eat me" signal: the dying cells expose "eat me" signals on their surface, so phagocytes can recognize and engulf apoptotic cells by recruiting a complex of receptors and bridging molecules. The main common "eat me" signals include the expression of phosphatidylserine (PS) on the outer layer of plasma membrane, brainspecific angiogenesis inhibitor 1, T cell immunoglobulin mucin receptor (TIM1, TIM3, TIM4), RAGE, and stabilin along with PS-specific bridging molecules, Gas6, Milk Fat Globule EGF Factor 8 (MFG-E8), and protein S. Other "eat me" signals include calreticulin (CRT) and ICAM3, which can modulate the identification and engulfment of apoptotic cells by LRP receptors (via C1q) and CD14, respectively. (C) The engulfment process: after recruitment of engulfment receptors through the activity of Rac pathway, the polymerization of actin and rearranging of cytoskeletal are initiated. Although the mechanism of TIM4 in this process is unknown, some engulfment receptors recruit the DOCK180/ELMO1 set ( $\alpha$ V $\beta 3$, TAM, stabilin-2, and LRP). Thus, disorders during this step can lead to autoimmunity and inflammatory.

may induce different effects. Third, the function of metabolites deriving from the extracellular breakdown of "find me" signals within the microenvironment surrounding dying cells needs to be clarified. Additional research addressing these issue might provide a better understanding of the impact in vivo of these signals both in physiological and pathological conditions.

\section{"Eat-Me" Signals}

The most effective "eat me" signal in well-organized efferocytosis is the extra-cellularly exposed lipid PS. The asymmetrical distribution of lipids in plasma membrane is well recognized; thus, PS is normally present in the inner leaflet in living cells, whereas it is expressed externally during the apoptotic process in a caspase-dependent manner (48). The mechanism for this translocation also includes the TMEM16F as a calcium-mediated cation channel, which can moderate lipid scrambling (49). On the other hand, the cleavage of the scramblase XKr8 by caspase- 3 can facilitate the expression of PS on the extra-cellular side of plasma membrane (50). In particular, it has been found that apoptotic stimuli may promote the formation of a plasma membrane complex between XKr8, basigin, and neuroplastin, which is required for the scrambling activity of XKr8 (51). Also, the activity of flippase ATP11C in transferring the aminophospholipids from outer leaflet to inner one during apoptosis is suppressed by caspase-3 cleavage, which can result in extra-cellularly PS exposure (52). PS, as the most critical "eat me" signal, has multiple receptors to be recognized by phagocytes including bona fide membrane receptors such as stablin-2 (53), RAGE (54), TIM4 (in addition to 
family members of TIM1 and TIM3) $(55,56)$, and brain-specific angiogenesis inhibitor 1 (57). Moreover, additional factors participate in PS recognition and dead cell engulfment including a number of bridging molecules like proteins, Gas6 (58), and MFG-E8 (59), as well as the associations between MFG-E8 and integrin $\alpha v \beta 3$ or $\alpha v \beta 5$ and those between Tyro3-Axl-Mer (TAM) family of receptors and proteins and Gas6 (60), CD14 and ICAM3 (61), and scavenger receptors like SR-A and oxidized LDL-like moieties (62). Also, the interaction between external CRT with complement C1q (63), and glycosylated surface protein with lectin (64) could be considered as additional contributor signals for apoptotic cell clearance. In particular, CRT may be expressed by apoptotic cells after a sequence of key events in the dying cells, including endoplasmic reticulum stress, eIF2alpha phosphorylation, caspase 8 activation, Bap31 cleavage, and Bax activation (65). The interaction between apoptotic cell surface CRT and phagocyte CD91 is then followed by apoptotic cell phagocytosis.

While exposure of PS is found in low levels on living cells, the presence of signals such as CD31, CD47, and CD61 on their surface is considered as a "do not eat me" signal for not being engulfed by phagocytes $(66,67)$. In this regard, the balance between "eat me" and "do not eat me" signals can more effectively and actively regulate the clearance of dying cells by phagocytes (5). There is also a cooperation between dying cells and phagocytes, so that cellular corpses can advertise their desire to be engulfed by phagocytes by expressing "find me" and "eat me" signals; on the other hand, the phagocytes can prompt their engulfment through employing receptors that distinguish these signals (3) (Figure 1B).

Overall, the role of the complex interplay between "eat me" and "do not eat me" signals and the pathological consequences of their derangement are far from being well understood. Further studies aimed at mapping with molecular probes the crucial players of the entire phagocytosis pathway induced by both "eat me" and "do not eat me" signals might help to elucidate this issue.

\section{Phagocytosis of Cellular Corpse}

The expression pattern, modes of identification, and downstream signaling of PS receptors are different. Beside professional phagocytes, PS receptors are expressed in different tissues including lungs (RAGE), kidneys (TIM-1), spleen (BAI-1), bone marrow (BAI-1), brain (BAI-1), and sinusoidal endothelium (stabilin-2) (36). There is an association between receptors and tissue specificity, explaining that different tissues need specialized PS receptors for efficient efferocytosis (3). For instance, expression of a defective BAI-1 in glial and neuronal cells can lead to apoptotic corpses accumulation and neurodegenerative disorders (68).

It has been shown that PS can be recognized by various domains of the above mentioned molecules (55). For example, stabilin-2 uses its EGF-like domains for PS identification (53), TIM receptors use their Ig-variable (IgV) domain (55) and MFG-E8 its C1 and C2 discoidin-like domains (69). Beside these, extracellular signaling (between PS and bridging molecules), intracellular signaling cascades are necessary to facilitate the engulfment of dead cells (70). Molecules such as Rho family of small GTPases involving Rock, Rac, RhoA, Rab 5, and CDC42 are also engaged to mediate the absorption of dead cells (71). These molecules are moderated between an inactive GDP-bound state and an activated
GTP-bound one by definite guanine-nucleotide-exchange factors as the bipartite GEF constituted by DOCK 180 and ELMO1 (72). The process of clearing the dead cells by phagocytes via active membrane disruption is also like macropinocytosis process (73), which is different from complement-receptor-mediated phagocytosis, so that the engulfment of corpse by negative regulation of RhoA is inhibited via its overexpression and it is dependent on Rho-associated coiled-coil-containing protein kinase (ROCK) (74). Using phosphorylation of myosin light chain, ROCK kinase activity can also induce actomyosin accumulation and cell contraction (73). Thus, the decrease of RhoA activation can result in the reduction of signaling by ROCK, lessening of stress fiber constitution, and preparing cell shape changes for efficient engulfment (74).

Unlike RhoA, the function of Rac1 in an evolutionarily preserved pathway is critical for developing phagocytic potential (71) since Rac1 activation can induce polymerization of actin and arrangement of cytoskeletal through Scar/WAVE composite (75, 76). Although the mechanism of CDC42 in the engulfment of dead cells by phagocytes is not precisely cleared (77), enclosing within the phagocyte and the downstream events of this metabolic pathway are started altogether (Figure 1C).

\section{Digestion and Immune Response}

The apoptotic cellular corpse, as an ingested cargo, includes several compounds (e.g., lipids, proteins, and others) that can force the phagocytes to remove them in an immunologic procedure (14). The fusion of the phagosomes with the lysosomes can lead to the activation of lysosome enzymes such as acid proteases and nucleases to destruct the apoptotic cell constituents. However, this process may lead to local inflammation. Thus, for instance, DNAse II is necessary for DNA degradation, a process that can be followed by aggregation of DNA fragments within phagocytes, which in turn may promote inflammation and polyarthritis $(78,79)$.

In order to maintain tissue homeostasis and to prevent inflammation, phagocytes with engulfed dead cells can produce anti-inflammatory cytokines, including TGF $\beta$ and interleukin-10 (80). The engulfment of apoptotic cells may also suppress proinflammatory cytokines (e.g., TNF-alpha, IL-1, IL-12) (81). In addition, via the activation of peroxisome proliferator-activated receptor $\gamma / \delta$, as an important regulator of cellular lipid homeostasis and apoptotic cell clearance, cholesterol can suppress inflammatory responses (82).

To manage the process of degradation of the cells, at least two definite pathways for engulfment of external or internal unwanted particles have been described, including phagocytosis and autophagy (83). More recently, LC3-associated phagocytosis (LAP) has been proposed as a novel non-canonical process of autophagy involving the clearance of extracellular apoptotic debris and pathogens. LAP, as a process combining the preserved pathways of phagocytosis and autophagy machinery, may be induced when extra-cellular molecules including pathogens, dead cells, or immune complexes are recognized by extra-cellular receptors such as toll-like receptor $1 / 2$ (TLR1/2), TLR2/6, TLR4, FCR, and TIM4 and result in the application of some members of the autophagy machinery to the cargo-containing vesicle (84). 
In spite of having common molecular machineries, there are multiple features to discriminate LAP from autophagy based on the structure of LC3-decorated phagosome (or LAPosome). It was elucidated that autophagosomes involve a bilayer membrane to surround autophagic cargo, whereas the LAP consisted of a monolayer membrane structure $(85,86)$. The formation of autophagosomes also takes long hours, whereas the phosphatidylinositol 3-phosphate (PI3P) activity in L3-decorated phagosome (LAPosome) is performed in a few minutes after phagocytosis $(86,87)$. Autophagy is also dependent on preinitiation complex including FIP200, ULK1/2, and ATG13 while LAP functions do not (84). Both autophagy and LAP require the class III PI3kinase complex and its core components of VPS34, VPS15, and Beclin-1; besides, LAP can recruit the UVRAG containing class III PI3kinase complex (88). The defensive role of LAP against autoimmune responses has also been established; accordingly, its failure can lead to a sustained pro-inflammatory status (86). However, the regulation of immune responses via LAP pathway needs further studies to be more clearly delineated (Figure 2).

\section{PATHOLOGIES ASSOCIATED WITH IMPROPER EFFEROCYTOSIS}

Apoptosis, as a well-organized mechanism, can play a critical role to adjust immune system and homeostasis. Thus, even a small failure in this multi-step procedure can lead to many disorders. If an apoptotic cell is not removed in a specific period of time, it is possible to be ruptured and finally dispense its harmful contents. Since these released particles are considered as autoantigens, they result in the promotion of immune responses $(89,90)$. In this respect, accumulating evidence demonstrates that impairment in the process of efferocytosis is straightly linked to the appearance of numerous autoimmune and inflammatory diseases such as SLE, RA, type I diabetes, multiple sclerosis (MS), and others, which are delineated as follows (91).

\section{Systemic Lupus Erythematous}

One of the autoimmune diseases that is strongly associated with impaired efferocytosis is SLE. This disease can cause a wide range of clinical symptoms through the involvement of skin, joints, kidney, lungs, nervous system, heart, and blood vessels (92). Since unengulfed apoptotic cells exist in the germinal centers of the lymph nodes of some patients with SLE and the extracted macrophages from these patients can reveal low ingestion ability of apoptotic cells, the failure of dead cells clearance can be attributed to be one of the reasons of SLE (93). Moreover, SLE patients have circulating autoantibodies against nuclear antigens [e.g., antinuclear antibodies (ANA) and anti-DNA antibodies] (94). Thus, the binding of autoantibodies with autoantigens leads to the constitution of immune complexes, which can participate to the etiopathogenesis of SLE-associated nephropathy (95).

Previous experiments conducted on mice with deficiency in one of the various receptors of efferocytosis including MFG-E8, BAI-1, TIM-4, or MerTK have demonstrated that dead cells were concentrated in their lymph nodes. In addition, they suffered from an SLE-like disease with splenomegaly and glomerulonephritis manifestations $(45,96,97)$. These mice also generated a high level of anti-double-stranded DNA and antinuclear antibodies. As well, abnormal splicing of MFGE-8 and failure of C1q complements in MFG-E8-deficient mice resulted in impaired engulfment of dead cells, secondary necrosis following the release of cellular compartments and production of autoantibodies (45). In this regard, mice affected with defective MFG-E8 are considered as good models for investigating the molecular process in which endogenous cellular constituents can stimulate the immune system extra-cellularly (45).

As explained above, at the early stage of programmed cell death, the apoptotic cells are distinguished and engulfed by macrophages mostly due to a PS-dependent way. Nevertheless, the mechanism of recognizing and engulfing necrotic cells via macrophages is not completely clarified. It has been hypothesized that the complement system may have a role in this process (98). At the early stage of apoptosis, $\mathrm{C} 1$ connects to dead cells through IgM-dependent manner and via the expression of LPC signals on them for IgM-binding (99). It is also verified that humans with deficient C1q gene are prone to develop SLE. In mice with C1q deficiency like MRL/Mp strain, unengulfed dead cells stimulate the development of SLE-like glomerulonephritis (100). It is interesting that some polymorphism in ATG5 (101) and likely ATG7 genes (102), engaged in both autophagy and LAP, have been identified through genomic studies as propensity markers for SLE $(84,85,87)$.

Among the different organs potentially affected by SLE, heart involvement may be of particular severity. In particular, QT interval prolongation, which may be promoted by both cardiomyocyte apoptosis (103) and chronic inflammation (104), is a common finding in SLE (105) and may increase the risk of cardiovascular complications (106). Since enhanced efferocytosis of apoptotic cardiomyocytes promotes inflammation resolution and cardiac repair (107), this might translate into improved electric impulse propagation as well. However, a better understanding of the involvement of efferocytosis in arrhythmias and cardiac involvement in SLE is still needed.

\section{Anemia and Polyarthritis}

When apoptotic cells are engulfed by phagocytes, they can be degraded within lysosomes into their constituents, including nucleotides, fatty acids, amino acids, and monosaccharides. DNA is also degraded within lysosomes via DNase II in acidic situations (108). DNase II is expressed in different tissues, especially in macrophages; therefore, insufficient DNase II in macrophages can result in the accumulation of nucleotides followed by production of cytokines by macrophages. IFN $\beta$, the main kind of cytokines produced by macrophages, is cytotoxic to lymphocytes and erythroblasts (109). Specifically, via TUNEL assay on mice, it was demonstrated that erythroblasts could be killed by IFN $\beta$ function; thus, severe anemia may occur following IFN $\beta$ exposure. Furthermore, severe anemia is also the cause of death in mice with DNase II deficiency in embryogenesis (78). Moreover, mice with both deficiency at DNase II and IFN-type I receptor or mice with deleted genes of DNAse II through knockout procedure after birth could promote polyarthritis (79). RA is a systemic and 


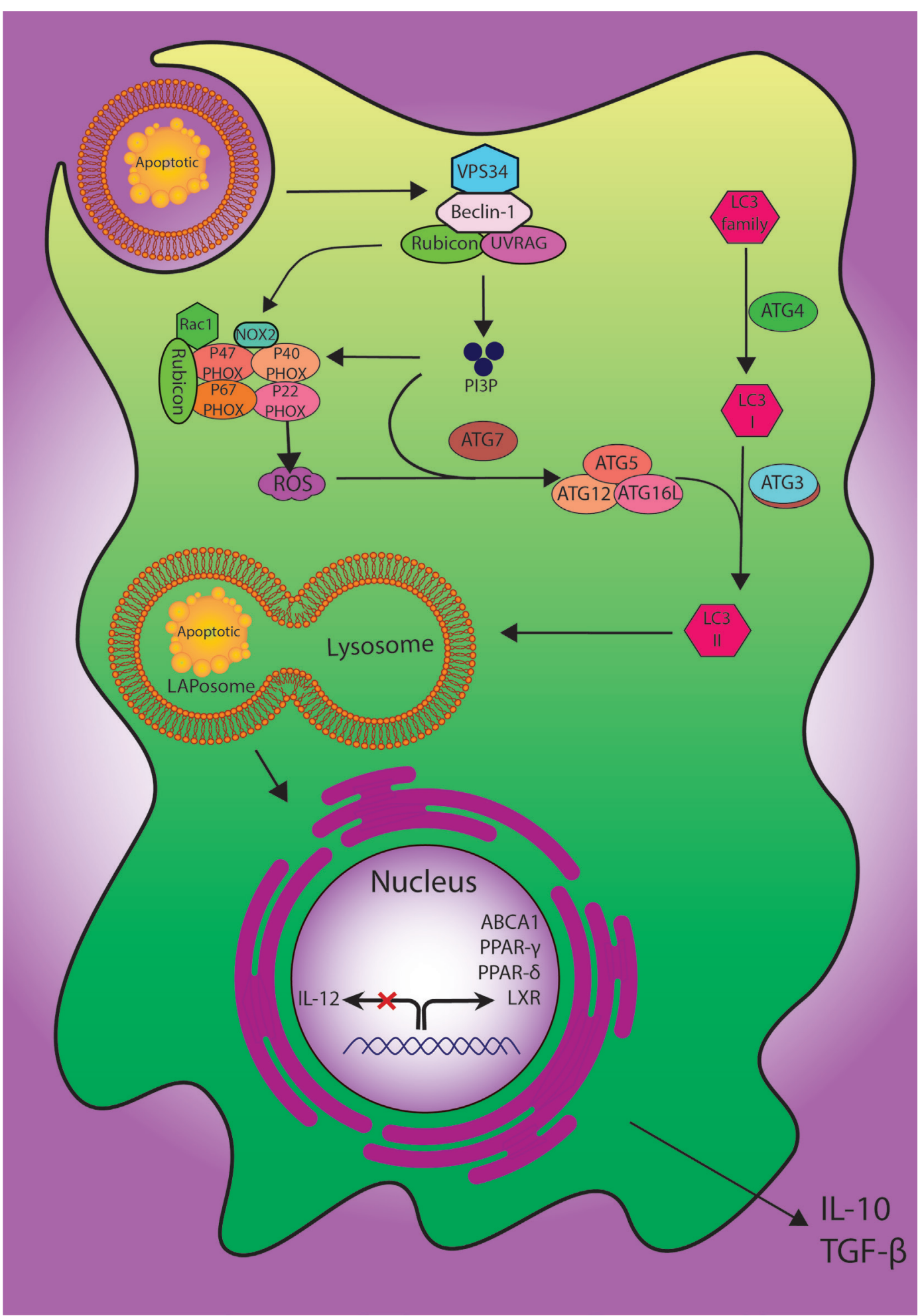

FIGURE 2 | The digestion process of engulfed dead cells. During the engulfment of apoptotic cells, LC3-associated phagocytosis (LAP) pathway accompanied by its components and ULK1/2 complex as a canonical autophagy pathway have specific roles. The class III PI3K collection involving VPS34, Beclin-1, UVRAG, and Rubicon are also important to the localization of PI3P at the LAPosome and canonical autophagy. PI3P has two functions: the employment of the downstream autophagic/LAP machinery including ATG5, ATG7, ATG12, and ATG16L, and fixation of the NOX2 set with recruitment of Rubicon. Also, merging the lysosome and LAPosome maturation is in need of LC3-II. The cholesterol sensors such as liver X receptor, ABCA1, PPARס, PPAR $\gamma$, and PGC-1 $\beta$ are similarly required for anti-inflammatory impact of efferocytosis, which can result in producing anti-inflammatory modulator such as IL-10 and TGF- $\beta$. 
chronic autoimmune disorder with inflammatory joint involvement, which can be manifested by developed circulating autoantibodies against citrullinated peptides or complement protein C3 and rheumatoid factor $(110,111)$. In the swollen joints of patients with RA, i.e., the site of joints with aggressive pannus formation and cartilage erosion, the genes of inflammatory cytokines such as IL-1 $\beta$, IL-6, and TNF $\alpha$ are activated (112). Hence, RA patients can be treated via antagonism of these cytokines (79).

Experiments on DNase II null mice showed undigested DNA expressing TNF- $\alpha$ mRNA in macrophages, and the presence of low levels of TNF- $\alpha$ in serum before detecting any abnormalities in the joints. TNF- $\alpha$ production via macrophages can be responsible for the promotion of polyarthritis (113). Synovial cells also respond to TNF- $\alpha$ in order to generate IL- $1 \beta$ and IL- 6 , trigger the expression of TNF- $\alpha$ gene (114), and consequently produce cytokines in the joint, which can result in polyarthritis development (115).

Anemia and polyarthritis may be related to DNase II deficiencies as a more complex lysosomal storage disease, caused by malfunction of lysosomal enzymes including glycosidases, proteases, and lipases. As a consequence, DNA, RNA, proteins, and polysaccharides of bacterial or viral origin can stimulate the innate immunity and generate different cytokines (116). Obtained from DNase II null mice, accumulated DNA in the lysosome of mammalian macrophages can activate the innate immune responses. It is likely that other undegraded components in lysosome stimulate IFN $\beta$ and TNF $\alpha$ genes. Secretion of cytokines by macrophages that are deficient in the production of lysosomal acid lipase (117) and by fibroblasts of patients with Niemann-Pick Disease Type C (118) can consequently support this fact. Treatment of some polyarthritis patients with bone marrow transplantation confirms the presence of a deficiency in bone-marrow-derived cells in these patients. Besides, determining whether there is a defect in their lysosomal enzyme could also be useful to develop a treatment procedure (119). Although there is not enough genetic evidence to link human RA and efferocytosis, studies have revealed the possibility to increase the amount of bridging molecules for TAM receptor or stimulating the liver $\mathrm{X}$ receptor/PPAR $\gamma$, which could have therapeutic advantages in mice with inflammatory arthritis (120).

\section{Type 1 Diabetes}

Pancreatic insulin-producing B cell destruction is responsible for development of T1D, a T cell-mediated autoimmune disorder leading to insulin deficiency and hyperglycemia. It is believed that inefficient clearance of apoptotic pancreatic cells may promote the release of signals and autoantigens into the media via the creation of necrosis and inflammation (121). The lack of T cell tolerance to self-antigens is also a critical factor in T1D patients. Recently, some studies have demonstrated that defective clearance of dead cells is in association with immunogenic responses (not tolerogenic), maturation of DC, and chronic inflammation. In this respect, a study on non-obese diabetic (NOD) mice, which instinctively develop TID mellitus, showed that there were not only defects in the process of apoptotic cell clearance by phagocytes in vitro, but also the efferocytosis mechanism through apoptotic stimulation had its own deficiencies in vivo. Thus, impaired apoptotic cell clearance by NOD mice contributed to the generation of ANA (122).

A common feature among patients with both Type1 and Type2 Diabetes mellitus is the imperfect wound healing. It has been observed that aggregation of dead cells at the site of the wound can lead to inflammation and slow wound healing as a result of incomplete efferocytosis $(123,124)$. Although the relationship between diabetes and efferocytosis has been investigated, the absolute mechanism of the effect has not been still recognized.

\section{Multiple Sclerosis}

Multiple Sclerosis is known as a chronic and degenerative disorder of the central nervous system (CNS), distinguished by focal lesions with inflammation, oligodendroglial death, demyelination, and axonal damage (125). These cellular changes are accompanied by neurological deficiencies such as sensory disruption, visual deficits, loss of motor regulation, and production of elevated level of IL- $1 \beta$ cytokine from monocytes and macrophages. MS is usually started with an autoimmune inflammatory response to myelin constitutions and develops to a chronic stage via degeneration of myelin, axons, and oligodendrocytes $(126,127)$. The most common reason for MS pathology is related to excitotoxicity, produced by primary and/or secondary changes in glutamate signaling (128). Via ATP as the main neurotransmitter in the CNS, ionotropic (P2X), and metabotropic (P2Y2) receptors are activated (129). Interestingly, both $\mathrm{P} 2 \mathrm{X}$ and $\mathrm{P} 2 \mathrm{Y}$ receptors have been involved in MS (130), with variable influence according to different P2X and P2Y subtypes. Furthermore, both P2X and P2Y have been found to recognize different "eat me" and "find me" signals during efferocytosis $(33,131)$. Thus, P2X and P2Y could be regarded as possible target in MS. However, it must be recognized that supportive data on how defective clearance of apoptotic neural cells contribute to MS pathogenesis are not still clarified. In particular, despite there is evidence that panx1 is the molecular substrate for P2X7 and P2X7 is involved in neuronal death and MS (132), the impact of P2X7 neuronal death on efferocytosis has not been defined. Hence, additional research is needed for a better comprehension on whether impaired efferocytosis may influence MS pathogenesis.

\section{Autoimmune Lymphoproliferative Syndrome (ALPS)}

The ALPS $(133,134)$ disease is an autoimmune disease characterized by impaired lymphocyte homeostasis and increased susceptibility to malignancies (135). The disease is manifested by hypergammaglobulinemia, increased level of FAS ligand (136), and IL-10 (137) in plasma, along with accumulation of double-negative $\mathrm{T}$ cells (CD4 ${ }^{-} \mathrm{CD} 8^{-} \mathrm{T}$ cells) (138). First, the disease was identified in an experimental mouse with FAS and FASL mutations (139), which are imperative for apoptosis mechanism. Moreover, it has been understood through further investigations on both mice and humans that the given factors as parts of the TNF receptor family are necessary for an apoptosis procedure in order to prevent the assembly of self-reactive $\mathrm{T}$ and B lymphocytes (140). In this regard, it is realized that defective apoptosis pathway can lead to the activation of immune system 
and manifest itself as a disease affecting other organs of the body due to mutation in FASL and deficit signaling pathway $(134,141)$. Hence, because FAS/FASL pathway may serve as a "find-me" signal in efferocytosis (142), it is arguable that mutations involving genes of this pathway, as observed in ALPS, might have also an impact on related diseases.

\section{Ulcerative Colitis}

One of the forms of inflammatory bowel disease (IBD) is ulcerative colitis. The given disease is considered as a chronic and relapsing disorder of the large intestine manifested by contiguous inflammation of the colonic lamina propria (143). A critical factor in the pathogenesis of the IBD is host identification of bacteria, which are sensed by the immune system via specific receptors resulting in inflammation (144). Lipopolysaccharide (LPS), as the main component of cell wall in bacteria, is also recognized by TLR-4, and it can result in NF- $\mathrm{BB}$-related stimulation of inflammatory responses (145). In this regard, mice with deficiency in TLR-4 have an impaired response to LPS. Since TLRs are key activators of innate immunity, insufficient activation of innate immune system via intestinal luminal antigen or deficient regulation of its signaling results in an imbalance between effectors and regulatory cells, leading to over-responsiveness to these bacteria and intestinal inflammation $(146,147)$. Besides TLRs, particularly TLR4, other molecules like LPS-binding protein and the bacterial permeability increasing protein (BPI) with a high affinity to LPS, have been reported in human serum $(148,149)$. These complexes, which are recognized by CD14, a glycosylphosphatidylinositolanchored molecule on the monocyte surface, are activated in the form of potent antimicrobial proteins (150). Since CD14 as a bridging gap is in connection with ICAM3, facilitating the recognition and engulfment of apoptotic cells results in efficient efferocytosis.

It has been demonstrated that two mutations in extracellular domain of TLR- 4 along with a polymorphism in the gene of CD14 contributed to ulcerative colitis (151). Moreover, it has been reported that individuals with both mutations of TLR- 4 in the airway epithelia do not respond to the induction of LPS; thus, the reduced expression of TLR was seen on their apical surface (152), which resulted in increased risk of bacterial infections (153). It was also realized that deficient receptors on the cells could not activate the signaling cascades of immunity to clear the bacterial infection; thus, they resulted in immune responses and the IBD (154-156).

\section{Crohn's Disease (CD)}

A kind of chronic inflammatory disease of the gastrointestinal tract is $\mathrm{CD}$, in which, altered immune response against intraluminal microbiota may occur in a susceptible host (157). There are several genes in association with $\mathrm{CD}$, but one of the most

\section{REFERENCES}

1. Tanaka M, Nishitai G. Immune regulation by dead cell clearance. Curr Top Microbiol Immunol (2017) 403:171-83.

2. Grimsley C, Ravichandran KS. Cues for apoptotic cell engulfment: eat-me, don't eat-me and come-get-me signals. Trends Cell Biol (2003) 13:648-56. doi:10.1016/j.tcb.2003.10.004 important is the nucleotide-binding oligomerization domain containing 2 or (NOD2) gene, known as CARD15 (158). The Nod-protein family is comprised of intra-cellular and hostspecific cytosolic pattern-recognition receptors with a significant role in innate immunity to detect pathogen-associated molecular patterns of different microorganisms in order to produce transcriptional responses against bacteria (159). In this regard, two genes can contribute to autophagy including autophagy-related 16-like 1 (ATG16L1) (160) and the immunity-related GTPase family M (IRGM) (161). Recent studies have also shed light on a relationship between Nod2 and autophagy pathway in which Nod2 recruits the ATG16L1 to the plasma membrane through the bacterial invasion; thus, patients with mutations in Nod2 have a deficiency in bacterial trafficking, autophagy induction, and antigen presentation, which result in steady inflammation (162). Beside these genes, the ULK1 is another autophagy gene contributing to $\mathrm{CD}$. It has been determined that the silencing of ULK1 can inhibit autophagy that finally results in accumulation of dead cells, acute immune responses, as well as inflammation in the gastrointestinal tract (159).

\section{CONCLUSION}

Apoptosis is a natural mechanism to maintain homeostasis and tissue development, which has been extensively studied. Due to the importance of programmed cell death, a deeper understanding of the mechanisms of this process, classification of its subtypes and pathological significance, as well as further comprehension of the relationship between diseases and cell death require additional clarification. However "postapoptotic biological events" have drawn the interest of many researchers. Indeed, the field of efferocytosis is rather young and numerous autoimmune disorders have been investigated to be correlated with impaired efferocytosis. However, there are many challenges in this field to be overcome such as the identification of various steps of efferocytosis mechanisms and their relation to diseases and understanding of the kinds of engulfing phagocytes and their relation to tissue specificity. Thus, the interest in examining efferocytosis and autoinflammatory disorders continues to grow. Precise understanding of efferocytosis and its biological and physiological roles in the autoimmune system can light new insights on how to prevent diseases in early stages and help with providing therapeutic methods to treat autoimmune disorders.

\section{AUTHOR CONTRIBUTIONS}

Discussed the review content: FA, $\mathrm{SH}$ and AS; wrote and critically revised the manuscript: FA, NF, SH, MP, VB, GB and AS; all authors agreed and approved the submission.

3. Poon IK, Lucas CD, Rossi AG, Ravichandran KS. Apoptotic cell clearance: basic biology and therapeutic potential. Nat Rev Immunol (2014) 14:166-80. doi:10.1038/nri3607

4. Yoon KW. Dead cell phagocytosis and innate immune checkpoint. BMB Rep (2017) 50:496. doi:10.5483/BMBRep.2017.50.10.147

5. Martinez J. Prix Fixe: efferocytosis as a four-course meal. Curr top microbiol immunol (2017) 403:1-36. doi:10.1007/82_2015_467 
6. Green D, Oguin T, Martinez J. The clearance of dying cells: table for two. Cell Death Differ (2016) 23:915-26. doi:10.1038/cdd.2015.172

7. Elmore S. Apoptosis: a review of programmed cell death. Toxicol Pathol (2007) 35:495-516. doi:10.1080/01926230701320337

8. Savill J, Fadok V. Corpse clearance defines the meaning of cell death. Nature (2000) 407:784. doi:10.1038/35037722

9. Fehr E-M, Kierschke S, Max R, Gerber A, Lorenz H-M, Schiller M. Apototic cell-derived membrane vesicles induce CD83 expression on human mdDC: brief definite report. Autoimmunity (2009) 42:322-4. doi:10.1080/08916930902832173

10. Kurosaka K, Takahashi M, Watanabe N, Kobayashi Y. Silent cleanup of very early apoptotic cells by macrophages. J Immunol (2003) 171:4672-9. doi:10.4049/jimmunol.171.9.4672

11. Rai NK, Tripathi K, Sharma D, Shukla VK. Apoptosis: a basic physiologic process in wound healing. Int J Low Extrem Wounds (2005) 4:138-44. doi:10.1177/1534734605280018

12. Bratton DL, Fadok VA, Richter DA, Kailey JM, Guthrie LA, Henson PM. Appearance of phosphatidylserine on apoptotic cells requires calciummediated nonspecific flip-flop and is enhanced by loss of the aminophospholipid translocase. J Biol Chem (1997) 272:26159-65. doi:10.1074/jbc.272.42. 26159

13. Arur S, Uche UE, Rezaul K, Fong M, Scranton V, Cowan AE, et al. Annexin I is an endogenous ligand that mediates apoptotic cell engulfment. Dev Cell (2003) 4:587-98. doi:10.1016/S1534-5807(03)00090-X

14. Biermann M, Maueröder C, Brauner JM, Chaurio R, Janko C, Herrmann M, et al. Surface code-biophysical signals for apoptotic cell clearance. Phys Biol (2013) 10:065007. doi:10.1088/1478-3975/10/6/065007

15. Rubio-Moscardo F, Blesa D, Mestre C, Siebert R, Balasas T, Benito A, et al. Characterization of 8p21. 3 chromosomal deletions in B-cell lymphoma: TRAIL-R1 and TRAIL-R2 as candidate dosage-dependent tumor suppressor genes. Blood (2005) 106:3214-22. doi:10.1182/blood-2005-05-2013

16. Wajant $\mathrm{H}$. The Fas signaling pathway: more than a paradigm. Science (2002) 296:1635-6. doi:10.1126/science.1071553

17. Hsu H, Xiong J, Goeddel DV. The TNF receptor 1-associated protein TRADD signals cell death and NF-אB activation. Cell (1995) 81:495-504. doi:10.1016/0092-8674(95)90070-5

18. Shi Y. Apoptosome: the cellular engine for the activation of caspase-9. Structure (2002) 10(3):285-8. doi:10.1016/S0969-2126(02)00732-3

19. Gonzalez D, Bejarano I, Barriga C, Rodriguez A, Pariente J. Oxidative stress-induced caspases are regulated in human myeloid HL-60 cells by calcium signal. Curr Signal Transduct Ther (2010) 5:181-6. doi:10.2174/ 157436210791112172

20. Fesik SW, Shi Y. Controlling the caspases. Science (2001) 294:1477-8. doi:10.1126/science.1062236

21. Pavlov EV, Priault M, Pietkiewicz D, Cheng EH-Y, Antonsson B, Manon S, et al. A novel, high conductance channel of mitochondria linked to apoptosis in mammalian cells and Bax expression in yeast. J Cell Biol (2001) 155:725-32. doi:10.1083/jcb.200107057

22. Sattler M, Liang H, Nettesheim D, Meadows RP, Harlan JE, Eberstadt M, et al. Structure of Bcl-xL-Bak peptide complex: recognition between regulators of apoptosis. Science (1997) 275:983-6. doi:10.1126/science.275. 5302.983

23. Li H, Zhu H, Xu C-J, Yuan J. Cleavage of BID by caspase 8 mediates the mitochondrial damage in the Fas pathway of apoptosis. Cell (1998) 94:491-501. doi:10.1016/S0092-8674(00)81590-1

24. Korsmeyer S, Wei M, Saito M, Weiler S, Oh K, Schlesinger P. Pro-apoptotic cascade activates BID, which oligomerizes BAK or BAX into pores that result in the release of cytochrome c. Cell Death Differ (2000) 7:1166. doi:10.1038/ sj.cdd. 4400783

25. Zhang D-W, Shao J, Lin J, Zhang N, Lu B-J, Lin S-C, et al. RIP3, an energy metabolism regulator that switches TNF-induced cell death from apoptosis to necrosis. Science (2009) 325:332-6. doi:10.1126/science.1172308

26. Hilbi $\mathrm{H}$, Chen $\mathrm{Y}$, Thirumalai $\mathrm{K}$, Zychlinsky A. The interleukin lbetaconverting enzyme, caspase 1 , is activated during Shigella flexneri-induced apoptosis in human monocyte-derived macrophages. Infect Immun (1997) 65:5165-70.

27. Yang WS, Sriramaratnam $R$, Welsch ME, Shimada K, Skouta R, Viswanathan VS, et al. Regulation of ferroptotic cancer cell death by GPX4. Cell (2014) 156:317-31. doi:10.1016/j.cell.2013.12.010
28. Peter C, Wesselborg S, Herrmann M, Lauber K. Dangerous attraction: phagocyte recruitment and danger signals of apoptotic and necrotic cells. Apoptosis (2010) 15:1007-28. doi:10.1007/s10495-010-0472-1

29. Hart SP, Dransfield I, Rossi AG. Phagocytosis of apoptotic cells. Methods (2008) 44:280-5. doi:10.1016/j.ymeth.2007.11.009

30. Monks J, Rosner D, Geske FJ, Lehman L, Hanson L, Neville M, et al. Epithelial cells as phagocytes: apoptotic epithelial cells are engulfed by mammary alveolar epithelial cells and repress inflammatory mediator release. Cell Death Differ (2005) 12:107. doi:10.1038/sj.cdd.4401517

31. Lee CS, Penberthy KK, Wheeler KM, Juncadella IJ, Vandenabeele P, Lysiak JJ, et al. Boosting apoptotic cell clearance by colonic epithelial cells attenuates inflammation in vivo. Immunity (2016) 44:807-20. doi:10.1016/j. immuni.2016.02.005

32. Ravichandran KS. Find-me and eat-me signals in apoptotic cell clearance: progress and conundrums. J Exp Med (2010) 207:1807-17. doi:10.1084/ jem. 20101157

33. Elliott MR, Chekeni FB, Trampont PC, Lazarowski ER, Kadl A, Walk SF, et al. Nucleotides released by apoptotic cells act as a find-me signal to promote phagocytic clearance. Nature (2009) 461:282-6. doi:10.1038/nature08296

34. Reddien PW, Horvitz HR. CED-2/CrkII and CED-10/Rac control phagocytosis and cell migration in Caenorhabditis elegans. Nat Cell Biol (2000) 2:131-6. doi:10.1038/35004000

35. Hoeppner DJ, Hengartner MO, Schnabel R. Engulfment genes cooperate with ced-3 to promote cell death in Caenorhabditis elegans. Nature (2001) 412:202-6. doi:10.1038/35084103

36. Hochreiter-Hufford A, Ravichandran KS. Clearing the dead: apoptotic cell sensing, recognition, engulfment, and digestion. Cold Spring Harb Perspect Biol (2013) 5:a008748. doi:10.1101/cshperspect.a008748

37. Chekeni FB, Elliott MR, Sandilos JK, Walk SF, Kinchen JM, Lazarowski ER, et al. Pannexin 1 channels mediate/find-me/'signal release and membrane permeability during apoptosis. Nature (2010) 467:863-7. doi:10.1038/ nature 09413

38. Truman LA, Ford CA, Pasikowska M, Pound JD, Wilkinson SJ, Dumitriu IE, et al. CX3CL1/fractalkine is released from apoptotic lymphocytes to stimulate macrophage chemotaxis. Blood (2008) 112:5026-36. doi:10.1182/blood2008-06-162404

39. Peter C, Waibel M, Keppeler H, Lehmann R, Xu G, Halama A, et al. Release of lysophospholipid 'find-me' signals during apoptosis requires the ATP-binding cassette transporter A1. Autoimmunity (2012) 45:568-73. doi:10.3109/ 08916934.2012.719947

40. Peter C, Waibel M, Radu CG, Yang LV, Witte ON, Schulze-Osthoff K, et al. Migration to apoptotic "find-me" signals is mediated via the phagocyte receptor G2A. J Biol Chem (2008) 283:5296-305. doi:10.1074/jbc.M706586200

41. Gude DR, Alvarez SE, Paugh SW, Mitra P, Yu J, Griffiths R, et al. Apoptosis induces expression of sphingosine kinase 1 to release sphingosine-1-phosphate as a "come-and-get-me" signal. FASEB J (2008) 22:2629-38. doi:10.1096/fj. 08-107169

42. Bournazou I, Pound JD, Duffin R, Bournazos S, Melville LA, Brown SB, et al. Apoptotic human cells inhibit migration of granulocytes via release of lactoferrin. J Clin Invest (2009) 119:20. doi:10.1172/JCI36226

43. Bournazou I, Mackenzie KJ, Duffin R, Rossi AG, Gregory CD. Inhibition of eosinophil migration by lactoferrin. Immunol Cell Biol (2010) 88:220-3. doi:10.1038/icb.2009.86

44. Kono H, Chen C-J, Ontiveros F, Rock KL. Uric acid promotes an acute inflammatory response to sterile cell death in mice. JClin Invest (2010) 120:1939. doi:10.1172/JCI40124

45. Hanayama R, Tanaka M, Miyasaka K, Aozasa K, Koike M, Uchiyama Y, et al. Autoimmune disease and impaired uptake of apoptotic cells in MFG-E8-deficient mice. Science (2004) 304:1147-50. doi:10.1126/science. 1094359

46. Krysko DV, Vandenabeele P. Clearance of dead cells: mechanisms, immune responses and implication in the development of diseases. Apoptosis (2010) 15:995-7. doi:10.1007/s10495-010-0524-6

47. Toda S, Hanayama R, Nagata S. Two-step engulfment of apoptotic cells. Mol Cell Biol (2012) 32:118-25. doi:10.1128/MCB.05993-11

48. Martin SJ, Finucane DM, Amarante-Mendes GP, O'brien GA, Green DR. Phosphatidylserine externalization during CD95-induced apoptosis of cells and cytoplasts requires ICE/CED-3 protease activity. J Biol Chem (1996) 271:28753-6. doi:10.1074/jbc.271.46.28753 
49. Suzuki J, Umeda M, Sims PJ, Nagata S. Calcium-dependent phospholipid scrambling by TMEM16F. Nature (2010) 468:834-8. doi:10.1038/ nature 09583

50. Suzuki J, Denning DP, Imanishi E, Horvitz HR, Nagata S. Xk-related protein 8 and CED-8 promote phosphatidylserine exposure in apoptotic cells. Science (2013) 341:403-6. doi:10.1126/science.1236758

51. Suzuki J, Imanishi E, Nagata S. Xkr8 phospholipid scrambling complex in apoptotic phosphatidylserine exposure. Proc Natl Acad Sci U S A (2016) 113:9509-14. doi:10.1073/pnas.1610403113

52. Segawa K, Kurata S, Yanagihashi Y, Brummelkamp TR, Matsuda F, Nagata S. Caspase-mediated cleavage of phospholipid flippase for apoptotic phosphatidylserine exposure. Science (2014) 344:1164-8. doi:10.1126/science. 1252809

53. Park S, Jung M, Kim H, Lee S, Kim S, Lee B, et al. Rapid cell corpse clearance by stabilin-2, a membrane phosphatidylserine receptor. Cell Death Differ (2008) 15:192-201. doi:10.1038/sj.cdd.4402242

54. He M, Kubo H, Morimoto K, Fujino N, Suzuki T, Takahasi T, et al. Receptor for advanced glycation end products binds to phosphatidylserine and assists in the clearance of apoptotic cells. EMBO Rep (2011) 12:358-64. doi:10.1038/ embor.2011.28

55. Santiago C, Ballesteros A, Martinez-Muñoz L, Mellado M, Kaplan GG, Freeman GJ, et al. Structures of $\mathrm{T}$ cell immunoglobulin mucin protein 4 show a metal-Ion-dependent ligand binding site where phosphatidylserine binds. Immunity (2007) 27:941-51. doi:10.1016/j.immuni.2007.11.008

56. DeKruyff RH, Bu X, Ballesteros A, Santiago C, Chim Y-LE, Lee H-H, et al. $\mathrm{T}$ cell/transmembrane, Ig, and mucin-3 allelic variants differentially recognize phosphatidylserine and mediate phagocytosis of apoptotic cells. J Immunol (2010) 184:1918-30. doi:10.4049/jimmunol.0903059

57. Park D, Tosello-Trampont A-C, Elliott MR, Lu M, Haney LB, Ma Z, et al. BAI1 is an engulfment receptor for apoptotic cells upstream of the ELMO/Dock180/Rac module. Nature (2007) 450:430-4. doi:10.1038/ nature 06329

58. Rothlin CV, Ghosh S, Zuniga EI, Oldstone MB, Lemke G. TAM receptors are pleiotropic inhibitors of the innate immune response. Cell (2007) 131:1124-36. doi:10.1016/j.cell.2007.10.034

59. Hu C-Y, Wu C-S, Tsai H-F, Chang S, Tsai W, Hsu PN. Genetic polymorphism in milk fat globule-EGF factor 8 (MFG-E8) is associated with systemic lupus erythematosus in human. Lupus (2009) 18:676-81. doi:10.1177/ 0961203309103027

60. Scott RS, Mcmahon EJ, Pop SM, Reap EA, Caricchio R, Cohen PL, et al. Phagocytosis and clearance of apoptotic cells is mediated by MER. Nature (2001) 411:207-11. doi:10.1038/35079659

61. Gregory C, Devitt A, Moffatt O. Roles of ICAM-3 and CD 14 in the Recognition and Phagocytosis of Apoptotic Cells by Macrophages. London: Portland Press Limited (1998).

62. Fadok VA, Warner ML, Bratton DL, Henson PM. CD36 is required for phagocytosis of apoptotic cells by human macrophages that use either a phosphatidylserine receptor or the vitronectin receptor ( $\alpha v \beta 3)$. J Immunol (1998) 161:6250-7.

63. Gardai SJ, Mcphillips KA, Frasch SC, Janssen WJ, Starefeldt A, MurphyUllrich JE, et al. Cell-surface calreticulin initiates clearance of viable or apoptotic cells through trans-activation of LRP on the phagocyte. Cell (2005) 123:321-34. doi:10.1016/j.cell.2005.08.032

64. Ezekowitz R, Sastry K, Bailly P, Warner A. Molecular characterization of the human macrophage mannose receptor: demonstration of multiple carbohydrate recognition-like domains and phagocytosis of yeasts in Cos-1 cells. J Exp Med (1990) 172:1785-94. doi:10.1084/jem.172.6.1785

65. Panaretakis T, Kepp O, Brockmeier U, Tesniere A, Bjorklund AC, Chapman DC, et al. Mechanisms of pre-apoptotic calreticulin exposure in immunogenic cell death. EMBO J (2009) 28:578-90. doi:10.1038/emboj.2009.1

66. Oldenborg P-A, Zheleznyak A, Fang Y-F, Lagenaur CF, Gresham HD, Lindberg FP. Role of CD47 as a marker of self on red blood cells. Science (2000) 288:2051-4. doi:10.1126/science.288.5473.2051

67. Elward K, Griffiths M, Mizuno M, Harris CL, Neal JW, Morgan BP, et al. CD46 plays a key role in tailoring innate immune recognition of apoptotic and necrotic cells. J Biol Chem (2005) 280:36342-54. doi:10.1074/jbc.M506579200

68. Mazaheri F, Breus O, Durdu S, Haas P, Wittbrodt J, Gilmour D, et al. Distinct roles for BAI1 and TIM-4 in the engulfment of dying neurons by microglia. Nat Commun (2014) 5:4046. doi:10.1038/ncomms5046
69. Hanayama R, Tanaka M, Miwa K, Shinohara A, Iwamatsu A, Nagata S. Identification of a factor that links apoptotic cells to phagocytes. Nature (2002) 417:182-7. doi:10.1038/417182a

70. Reddien PW, Horvitz HR. The engulfment process of programmed cell death in Caenorhabditis elegans. Annu Rev Cell Dev Biol (2004) 20:193-221. doi:10.1146/annurev.cellbio.20.022003.114619

71. Nakaya M, Tanaka M, Okabe Y, Hanayama R, Nagata S. Opposite effects of rho family GTPases on engulfment of apoptotic cells by macrophages. J Biol Chem (2006) 281:8836-42. doi:10.1074/jbc.M510972200

72. Brugnera E, Haney L, Grimsley C, Lu M, Walk SF, Tosello-Trampont A-C, et al. Unconventional Rac-GEF activity is mediated through the Dock180ELMO complex. Nat Cell Biol (2002) 4:574-82. doi:10.1038/ncb824

73. Riento K, Ridley AJ. Rocks: multifunctional kinases in cell behaviour. Nat Rev Mol Cell Biol (2003) 4:446-56. doi:10.1038/nrm1128

74. Erwig L-P, Mcphilips KA, Wynes MW, Ivetic A, Ridley AJ, Henson PM. Differential regulation of phagosome maturation in macrophages and dendritic cells mediated by Rho GTPases and ezrin-radixin-moesin (ERM) proteins. Proc Natl Acad Sci U S A (2006) 103:12825-30. doi:10.1073/pnas. 0605331103

75. Miki H, Suetsugu S, Takenawa T. WAVE, a novel WASP-family protein involved in actin reorganization induced by Rac. EMBO J (1998) 17:6932-41. doi:10.1093/emboj/17.23.6932

76. Castellano F, Montcourrier P, Chavrier P. Membrane recruitment of Rac1 triggers phagocytosis. J Cell Sci (2000) 113:2955-61.

77. Leverrier Y, Lorenzi R, Blundell MP, Brickell P, Kinnon C, Ridley AJ, et al. Cutting edge: the Wiskott-Aldrich syndrome protein is required for efficient phagocytosis of apoptotic cells. J Immunol (2001) 166:4831-4. doi:10.4049/ jimmunol.166.8.4831

78. Kawane K, Fukuyama H, Kondoh G, Takeda J, Ohsawa Y, Uchiyama Y, et al. Requirement of DNase II for definitive erythropoiesis in the mouse fetal liver. Science (2001) 292:1546-9. doi:10.1126/science.292.5521.1546

79. Kawane K, Ohtani M, Miwa K, Kizawa T, Kanbara Y, Yoshioka Y, et al. Chronic polyarthritis caused by mammalian DNA that escapes from degradation in macrophages. Nature (2006) 443:998-1002. doi:10.1038/nature05245

80. Fadok VA, Bratton DL, Konowal A, Freed PW, Westcott JY, Henson PM. Macrophages that have ingested apoptotic cells in vitro inhibit proinflammatory cytokine production through autocrine/paracrine mechanisms involving TGF-beta, PGE2, and PAF. JClin Invest (1998) 101:890. doi:10.1172/ JCI1112

81. Kim S, Elkon KB, Ma X. Transcriptional suppression of interleukin-12 gene expression following phagocytosis of apoptotic cells. Immunity (2004) 21:643-53. doi:10.1016/j.immuni.2004.09.009

82. Mukundan L, Odegaard JI, Morel CR, Heredia JE, Mwangi JW, RicardoGonzalez RR, et al. PPAR- $\delta$ senses and orchestrates clearance of apoptotic cells to promote tolerance. Nat Med (2009) 15:1266-72. doi:10.1038/ nm.2048

83. Martinez J, Verbist K, Wang R, Green DR. The relationship between metabolism and the autophagy machinery during the innate immune response. Cell Metab (2013) 17:895-900. doi:10.1016/j.cmet.2013.05.012

84. Florey O, Kim SE, Sandoval CP, Haynes CM, Overholtzer M. Autophagy machinery mediates macroendocytic processing and entotic cell death by targeting single membranes. Nat Cell Biol (2011) 13:1335-43. doi:10.1038/ ncb2363

85. Mizushima N, Ohsumi Y, Yoshimori T. Autophagosome formation in mammalian cells. Cell Struct Funct (2002) 27:421-9. doi:10.1247/csf. 27.421

86. Sanjuan MA, Dillon CP, Tait SW, Moshiach S, Dorsey F, Connell S, et al. Toll-like receptor signalling in macrophages links the autophagy pathway to phagocytosis. Nature (2007) 450:1253-7. doi:10.1038/nature06421

87. Henault J, Martinez J, Riggs JM, Tian J, Mehta P, Clarke L, et al. Noncanonical autophagy is required for type I interferon secretion in response to DNAimmune complexes. Immunity (2012) 37:986-97. doi:10.1016/j.immuni.2012. 09.014

88. Martinez J, Malireddi RS, Lu Q, Cunha LD, Pelletier S, Gingras S, et al. Molecular characterization of LC3-associated phagocytosis reveals distinct roles for Rubicon, NOX2 and autophagy proteins. Nat Cell Biol (2015) 17:893-906. doi:10.1038/ncb3192

89. Rovere P, Sabbadini MG, Fazzini F, Bondanza A, Zimmermann VS, Rugarli C, et al. Remnants of suicidal cells fostering systemic autoaggression: apoptosis in 
the origin and maintenance of autoimmunity. Arthritis Rheum (2000) 43: 1663-72. doi:10.1002/1529-0131(200008)43:8<1663::AID-ANR1>3.0.CO;2-1

90. Kuenkele S, Beyer TD, Voll RE, Kalden JR, Herrmann M. Impaired clearance of apoptotic cells in systemic lupus erythematosus: challenge of $\mathrm{T}$ and B cell tolerance. Curr Rheumatol Rep (2003) 5:175-7. doi:10.1007/s11926003-0061-1

91. Herrmann M, Voll RE, Zoller OM, Hagenhofer M, Ponner BB, Kalden JR. Impaired phagocytosis of apoptotic cell material by monocyte-derived macrophages from patients with systemic lupus erythematosus. Arthritis Rheum (1998) 41:1241-50. doi:10.1002/1529-0131(199807)41:7<1241::AID-ART15>3.0. $\mathrm{CO} ; 2-\mathrm{H}$

92. Cancro MP, D'cruz DP, Khamashta MA. The role of B lymphocyte stimulator (BLyS) in systemic lupus erythematosus. JClin Invest (2009) 119:1066. doi:10.1172/JCI38010

93. Gaipl U, Kuhn A, Sheriff A, Munoz L, Franz S, Voll R, et al. Clearance of apoptotic cells in human SLE. In: Elkon K, editor. Apoptosis and Its Relevance to Autoimmunity. Karger Publishers (2006). p. 173-87.

94. Rumore PM, Steinman CR. Endogenous circulating DNA in systemic lupus erythematosus. Occurrence as multimeric complexes bound to histone. J Clin Invest (1990) 86:69. doi:10.1172/JCI114716

95. Van Bruggen M, Kramers C, Walgreen B, Elema J, Kallenberg C, Van Den Born J, et al. Nucleosomes and histones are present in glomerular deposits in human lupus nephritis. Nephrol Dial Transplant (1997) 12:57-66. doi:10.1093/ndt/12.1.57

96. Cohen PL, Caricchio R, Abraham V, Camenisch TD, Jennette JC, Roubey RA, et al. Delayed apoptotic cell clearance and lupus-like autoimmunity in mice lacking the c-mer membrane tyrosine kinase. J Exp Med (2002) 196:135-40. doi:10.1084/jem.20012094

97. Rodriguez-Manzanet R, Sanjuan MA, Wu HY, Quintana FJ, Xiao S, Anderson AC, et al. T and B cell hyperactivity and autoimmunity associated with niche-specific defects in apoptotic body clearance in TIM-4-deficient mice. Proc Natl Acad Sci U S A (2010) 107:8706-11. doi:10.1073/pnas. 0910359107

98. Trouw L, Blom A, Gasque P. Role of complement and complement regulators in the removal of apoptotic cells. Mol Immunol (2008) 45:1199-207. doi:10.1016/j.molimm.2007.09.008

99. Kim SJ, Gershov D, Ma X, Brot N, Elkon KB. I-PLA2 activation during apoptosis promotes the exposure of membrane lysophosphatidylcholine leading to binding by natural immunoglobulin $\mathrm{M}$ antibodies and complement activation. J Exp Med (2002) 196:655-65. doi:10.1084/jem. 20020542

100. Potter PK, Cortes-Hernandez J, Quartier P, Botto M, Walport MJ. Lupus-prone mice have an abnormal response to thioglycolate and an impaired clearance of apoptotic cells. J Immunol (2003) 170:3223-32. doi:10.4049/jimmunol. 170.6 .3223

101. Zhou X-J, Lu X-L, Lv J-C, Yang H-Z, Qin L-X, Zhao M-H, et al. Genetic association of PRDM1-ATG5 intergenic region and autophagy with systemic lupus erythematosus in a Chinese population. Ann Rheum Dis (2011) 70:1330-7. doi:10.1136/ard.2010.140111

102. Clarke AJ, Ellinghaus U, Cortini A, Stranks A, Simon AK, Botto M, et al. Autophagy is activated in systemic lupus erythematosus and required for plasmablast development. Ann Rheum Dis (2014) 74(5):912-20. doi:10.1136/ annrheumdis-2013-204343

103. Zhang T, Yong SL, Drinko JK, Popovic ZB, Shryock JC, Belardinelli L, et al. LQTS mutation N1325S in cardiac sodium channel gene SCN5A causes cardiomyocyte apoptosis, cardiac fibrosis and contractile dysfunction in mice. Int J Cardiol (2011) 147:239-45. doi:10.1016/j.ijcard.2009.08.047

104. Lazzerini PE, Acampa M, Capecchi PL, Hammoud M, Maffei S, Bisogno S, et al. Association between high sensitivity C-reactive protein, heart rate variability and corrected QT interval in patients with chronic inflammatory arthritis. Eur J Intern Med (2013) 24:368-74. doi:10.1016/j.ejim.2013.02.009

105. Lazzerini PE, Capecchi PL, Laghi-Pasini F. Assessing QT interval in patients with autoimmune chronic inflammatory diseases: perils and pitfalls. Lupus Sci Med (2016) 3:e000189. doi:10.1136/lupus-2016-000189

106. Schillaci G, Pirro M, Ronti T, Gemelli F, Pucci G, Innocente S, et al. Prognostic impact of prolonged ventricular repolarization in hypertension. Arch Intern Med (2006) 166:909-13. doi:10.1001/archinte.166.19.2157-b

107. Wan E, Yeap XY, Dehn S, Terry R, Novak M, Zhang S, et al. Enhanced efferocytosis of apoptotic cardiomyocytes through myeloid-epithelial-reproductive tyrosine kinase links acute inflammation resolution to cardiac repair after infarction. Circ Res (2013) 113:1004-12. doi:10.1161/CIRCRESAHA.113. 301198

108. Kawane K, Fukuyama H, Yoshida H, Nagase H, Ohsawa Y, Uchiyama Y, et al. Impaired thymic development in mouse embryos deficient in apoptotic DNA degradation. Nat Immunol (2003) 4:138-44. doi:10.1038/ni881

109. Yoshida H, Okabe Y, Kawane K, Fukuyama H, Nagata S. Lethal anemia caused by interferon- $\beta$ produced in mouse embryos carrying undigested DNA. Nat Immunol (2005) 6:49-56. doi:10.1038/ni1146

110. Luban S, Li ZG. Citrullinated peptide and its relevance to rheumatoid arthritis: an update. Int J Rheum Dis (2010) 13:284-7. doi:10.1111/j.1756-185X. 2010.01553.x

111. Kenyon KD, Cole C, Crawford F, Kappler JW, Thurman JM, Bratton DL, et al. IgG autoantibodies against deposited C3 inhibit macrophage-mediated apoptotic cell engulfment in systemic autoimmunity. J Immunol (2011) 187:2101-11. doi:10.4049/jimmunol.1003468

112. Feldmann M. Development of anti-TNF therapy for rheumatoid arthritis. Nat Rev Immunol (2002) 2:364-71. doi:10.1038/nri802

113. Keffer J, Probert L, Cazlaris H, Georgopoulos S, Kaslaris E, Kioussis D, et al. Transgenic mice expressing human tumour necrosis factor: a predictive genetic model of arthritis. EMBO J (1991) 10:4025.

114. Taberner M, Scott K, Weininger L, Mackay C, Rolph M. Overlapping gene expression profiles in rheumatoid fibroblast-like synoviocytes induced by the proinflammatory cytokines interleukin- $1 \AA$ and tumor necrosis factor. Inflamm Res (2005) 54:10-6. doi:10.1007/s00011-004-1315-8

115. Migita K, Tanaka F, Yamasaki S, Shibatomi K, Ida H, Kawakami A, et al. Regulation of rheumatoid synoviocyte proliferation by endogenous p53 induction. Clin Exp Immunol (2001) 126:334-8. doi:10.1046/j.1365-2249.2001. 01677.x

116. Uematsu S, Akira S. Toll-like receptors and type I interferons. J Biol Chem (2007) 282:15319-23. doi:10.1074/jbc.R700009200

117. Lian X, Yan C, Yang L, Xu Y, Du H. Lysosomal acid lipase deficiency causes respiratory inflammation and destruction in the lung. Am J Physiol-Lung Cell Mol Physiol (2004) 286:L801-7. doi:10.1152/ajplung.00335.2003

118. Suzuki M, Sugimoto Y, Ohsaki Y, Ueno M, Kato S, Kitamura Y, et al. Endosomal accumulation of toll-like receptor 4 causes constitutive secretion of cytokines and activation of signal transducers and activators of transcription in Niemann-Pick disease type C (NPC) fibroblasts: a potential basis for glial cell activation in the NPC brain. J Neurosci (2007) 27: 1879-91. doi:10.1523/JNEUROSCI.5282-06.2007

119. Ikehara S. Bone marrow transplantation: a new strategy for intractable diseases. Drugs Today (Barc) (2002) 38:103-11. doi:10.1358/dot.2002.38.2. 820106

120. Park M-C, Kwon Y-J, Chung S-J, Park Y-B, Lee S-K. Liver X receptor agonist prevents the evolution of collagen-induced arthritis in mice. Rheumatology (2010) 49:882-90. doi:10.1093/rheumatology/keq007

121. Heimberg H, Heremans Y, Jobin C, Leemans R, Cardozo AK, Darville M, et al. Inhibition of cytokine-induced NF- $\mathrm{kB}$ activation by adenovirus-mediated expression of a NF- $\mathrm{kB}$ super-repressor prevents $\beta$-cell apoptosis. Diabetes (2001) 50:2219-24. doi:10.2337/diabetes.50.10.2219

122. O'Brien BA, Geng X, Orteu CH, Huang Y, Ghoreishi M, Zhang Y, et al. A deficiency in the in vivo clearance of apoptotic cells is a feature of the NOD mouse. JAutoimmun (2006) 26:104-15. doi:10.1016/j.jaut.2005. 11.006

123. Maruyama K, Asai J, Ii M, Thorne T, Losordo DW, D’amore PA. Decreased macrophage number and activation lead to reduced lymphatic vessel formation and contribute to impaired diabetic wound healing. Am J Pathol (2007) 170:1178-91. doi:10.2353/ajpath.2007.060018

124. Khanna S, Biswas S, Shang Y, Collard E, Azad A, Kauh C, et al. Macrophage dysfunction impairs resolution of inflammation in the wounds of diabetic mice. PLoS One (2010) 5:e9539. doi:10.1371/journal.pone.0009539

125. Matute C, Torre I, Pérez-Cerdá F, Pérez-Samartín A, Alberdi E, Etxebarria E, et al. P2X7 receptor blockade prevents ATP excitotoxicity in oligodendrocytes and ameliorates experimental autoimmune encephalomyelitis. J Neurosci (2007) 27:9525-33. doi:10.1523/JNEUROSCI.0579-07.2007

126. Steinman L. Multiple sclerosis: a two-stage disease. Nat Immunol (2001) 2:762. doi:10.1038/ni0901-762

127. Lassmann H. Multiple sclerosis pathology: evolution of pathogenetic concepts. Brain Pathol (2005) 15:217-22. doi:10.1111/j.1750-3639.2005.tb00523.x 
128. Vallejo-Illarramendi A, Domercq M, Pérez-Cerdá F, Ravid R, Matute C. Increased expression and function of glutamate transporters in multiple sclerosis. Neurobiol Dis (2006) 21:154-64. doi:10.1016/j.nbd.2005.06.017

129. North RA. Molecular physiology of P2X receptors. Physiol Rev (2002) 82:1013-67. doi:10.1152/physrev.00015.2002

130. Burnstock G. Purinergic signalling. Br J Pharmacol (2006) 147(Suppl 1): S172-81. doi:10.1038/sj.bjp.0706429

131. Marques-Da-Silva C, Burnstock G, Ojcius DM, Coutinho-Silva R. Purinergic receptor agonists modulate phagocytosis and clearance of apoptotic cells in macrophages. Immunobiology (2011) 216:1-11. doi:10.1016/j.imbio.2010. 03.010

132. Locovei S, Scemes E, Qiu F, Spray DC, Dahl G. Pannexin1 is part of the pore forming unit of the P2X7 receptor death complex. FEBS Lett (2007) 581:483-8. doi:10.1016/j.febslet.2006.12.056

133. Rieux-Laucat F, Le Deist F, Hivroz CEA, Roberts I, Debatin K, Fischer A, et al. Mutations in Fas associated with human lymphoproliferative syndrome and autoimmunity. Science (1995) 268:1347-9. doi:10.1126/science. 7539157

134. Magerus-Chatinet A, Stolzenberg M-C, Lanzarotti N, Neven B, Daussy C, Picard C, et al. Autoimmune lymphoproliferative syndrome caused by a homozygous null FAS ligand (FASLG) mutation. JAllergy Clin Immunol (2013) 131:486-90. doi:10.1016/j.jaci.2012.06.011

135. Straus SE, Jaffe ES, Puck JM, Dale JK, Elkon KB, Rösen-Wolff A, et al. The development of lymphomas in families with autoimmune lymphoproliferative syndrome with germline Fas mutations and defective lymphocyte apoptosis. Blood (2001) 98:194-200. doi:10.1182/blood.V98.1.194

136. Magerus-Chatinet A, Stolzenberg M-C, Loffredo MS, Neven B, Schaffner C, Ducrot N, et al. FAS-L, IL-10, and double-negative CD4-CD8-TCR alpha/ beta $+\mathrm{T}$ cells are reliable markers of ALPS associated with FAS loss of function. Blood (2009) 113:3027-30. doi:10.1182/blood-2008-09-179630

137. Lopatin U, Yao X, Williams RK, Bleesing JJ, Dale JK, Wong D, et al. Increases in circulating and lymphoid tissue interleukin-10 in autoimmune lymphoproliferative syndrome are associated with disease expression. Blood (2001) 97:3161-70. doi:10.1182/blood.V97.10.3161

138. Bleesing JJ, Brown MR, Dale JK, Straus SE, Lenardo MJ, Puck JM, et al. $\mathrm{TcR}-\alpha / \beta+\mathrm{CD} 4-\mathrm{CD} 8-\mathrm{T}$ cells in humans with the autoimmune lymphoproliferative syndrome express a novel CD45 isoform that is analogous to murine B220 and represents a marker of altered O-glycan biosynthesis. Clin Immunol (2001) 100:314-24. doi:10.1006/clim.2001.5069

139. Choi Y, Ramnath VR, Eaton AS, Chen A, Simon-Stoos KL, Kleiner DE, et al. Expression in transgenic mice of dominant interfering Fas mutations: a model for human autoimmune lymphoproliferative syndrome. Clin Immunol (1999) 93:34-45. doi:10.1006/clim.1999.4767

140. Hao Z, Duncan GS, Seagal J, Su Y-W, Hong C, Haight J, et al. Fas receptor expression in germinal-center B cells is essential for $\mathrm{T}$ and B lymphocyte homeostasis. Immunity (2008) 29:615-27. doi:10.1016/j.immuni.2008.07.016

141. Wang J, Zheng L, Lobito A, Chan FK-M, Dale J, Sneller M, et al. Inherited human Caspase 10 mutations underlie defective lymphocyte and dendritic cell apoptosis in autoimmune lymphoproliferative syndrome type II. Cell (1999) 98:47-58. doi:10.1016/S0092-8674(00)80605-4

142. Cullen SP, Henry CM, Kearney CJ, Logue SE, Feoktistova M, Tynan GA, et al. Fas/CD95-induced chemokines can serve as "find-me" signals for apoptotic cells. Mol Cell (2013) 49:1034-48. doi:10.1016/j.molcel.2013.01.025

143. Podolsky DK. Inflammatory bowel disease. N Engl J Med (1991) 325:928-37. doi:10.1056/NEJM199109263251306

144. Hoffmann JA, Kafatos FC, Janeway CA, Ezekowitz R. Phylogenetic perspectives in innate immunity. Science (1999) 284:1313-8. doi:10.1126/ science.284.5418.1313

145. Medzhitov R, Preston-Hurlburt P, Janeway CA Jr. A human homologue of the Drosophila toll protein signals activation of adaptive immunity. Nature (1997) 388:394. doi:10.1038/41131

146. Hoshino K, Takeuchi O, Kawai T, Sanjo H, Ogawa T, Takeda Y, et al. Cutting edge: toll-like receptor 4 (TLR4)-deficient mice are hyporesponsive to lipopolysaccharide: evidence for TLR4 as the Lps gene product. J Immunol (1999) 162:3749-52.
147. Qureshi ST, Larivière L, Leveque G, Clermont S, Moore KJ, Gros P, et al. Endotoxin-tolerant mice have mutations in toll-like receptor 4 (Tlr4). J Exp Med (1999) 189:615-25. doi:10.1084/jem.189.4.615

148. Weiss J, Muello K, Victor M, Elsbach P. The role of lipopolysaccharides in the action of the bactericidal/permeability-increasing neutrophil protein on the bacterial envelope. J Immunol (1984) 132:3109-15.

149. Schumann RR, Flaggs G, Gray P, Wright S, Mathison J, Tobias P, et al. Structure and function of lipopolysaccharide binding protein. Science (1990) 249:1429-31. doi:10.1126/science.2402637

150. Weiss J. Bactericidal/Permeability-Increasing Protein (BPI) and LipopolysaccharideBinding Protein (LBP): Structure, Function and Regulation in Host Defence Against Gram-Negative Bacteria. London: Portland Press Limited (2003).

151. Temple S, Cheong K, Almeida C, Price P, Waterer G. Polymorphisms in lymphotoxin alpha and CD14 genes influence TNF $\alpha$ production induced by Gram-positive and Gram-negative bacteria. Genes Immun (2003) 4:283. doi:10.1038/sj.gene.6363963

152. Arbour NC, Lorenz E, Schutte BC, Zabner J, Kline JN, Jones M, et al. TLR4 mutations are associated with endotoxin hyporesponsiveness in humans. Nat Genet (2000) 25:187. doi:10.1038/76048

153. Lorenz E, Mira JP, Frees KL, Schwartz DA. Relevance of mutations in the TLR4 receptor in patients with gram-negative septic shock. Arch Intern Med (2002) 162:1028-32. doi:10.1001/archinte.162.9.1028

154. Targan SR, Karp LC. Defects in mucosal immunity leading to ulcerative colitis. Immunol Rev (2005) 206:296-305. doi:10.1111/j.0105-2896.2005. 00286.x

155. Török H-P, Glas J, Tonenchi L, Mussack T, Folwaczny C. Polymorphisms of the lipopolysaccharide-signaling complex in inflammatory bowel disease: association of a mutation in the toll-like receptor 4 gene with ulcerative colitis. Clin Immunol (2004) 112:85-91. doi:10.1016/j.clim.2004.03.002

156. Baird AC, Mallon D, Radford-Smith G, Boyer J, Piche T, Prescott SL, et al. Dysregulation of innate immunity in ulcerative colitis patients who fail anti-tumor necrosis factor therapy. World J Gastroenterol (2016) 22:9104. doi:10.3748/wjg.v22.i41.9104

157. Cho JH. The genetics and immunopathogenesis of inflammatory bowel disease. Nat Rev Immunol (2008) 8:458-66. doi:10.1038/nri2340

158. Hugot J-P, Chamaillard M, Zouali H, Lesage S, Cézard J-P, Belaiche J, et al. Association of NOD2 leucine-rich repeat variants with susceptibility to Crohn's disease. Nature (2001) 411:599-603. doi:10.1038/35079107

159. Henckaerts L, Cleynen I, Brinar M, John JM, Van Steen K, Rutgeerts P, et al. Genetic variation in the autophagy gene ULK1 and risk of Crohn's disease. Inflamm Bowel Dis (2011) 17:1392-7. doi:10.1002/ibd.21486

160. Rioux JD, Xavier RJ, Taylor KD, Silverberg MS, Goyette P, Huett A, et al. Genome-wide association study identifies new susceptibility loci for Crohn disease and implicates autophagy in disease pathogenesis. Nat Genet (2007) 39:596-604. doi:10.1038/ng2032

161. Raelson JV, Little RD, Ruether A, Fournier H, Paquin B, Van Eerdewegh P, et al. Genome-wide association study for Crohn's disease in the Quebec founder population identifies multiple validated disease loci. Proc Natl Acad Sci U S A (2007) 104:14747-52. doi:10.1073/pnas.0706645104

162. Travassos LH, Carneiro LA, Ramjeet M, Hussey S, Kim Y-G, Magalhães JG, et al. Nod1 and Nod2 direct autophagy by recruiting ATG16L1 to the plasma membrane at the site of bacterial entry. Nat Immunol (2010) 11:55-62. doi:10.1038/ni.1823

Conflict of Interest Statement: The authors declare that the research was conducted in the absence of any commercial or financial relationships that could be construed as a potential conflict of interest.

Copyright (๑) 2018 Abdolmaleki, Farahani, Gheibi Hayat, Pirro, Bianconi, Barreto and Sahebkar. This is an open-access article distributed under the terms of the Creative Commons Attribution License (CC BY). The use, distribution or reproduction in other forums is permitted, provided the original author(s) and the copyright owner(s) are credited and that the original publication in this journal is cited, in accordance with accepted academic practice. No use, distribution or reproduction is permitted which does not comply with these terms. 